\title{
2015 Presidential Election in Nigeria: Reasons Why Incumbent President Good luck Jonathan Lost to Buhari
}

\author{
Odoh Patrick Abutu (Ph.D Student), Dr. Ku Hasnita Ku Samsu \\ ${ }^{I}$ Department of Government and Civilization Studies Faculty of Human Ecology Universiti Putra Malaysia \\ 43400 Serdang, Selangor MALAYSIA \\ ${ }^{I}$ Senior Lecturer Department of Government and Civilization Studies Faculty of Human Ecology Universiti \\ Putra Malaysia 43400 Serdang, Selangor MALAYSIA
}

\begin{abstract}
The Nigeria's 2015 Presidential election held on the $28^{\text {th }}$ March, 2015 was the $5^{\text {th }}$ quadrennial election of the Fourth Republic which defiled military interruption for sixteen (16) years. Apart from being the fifth election, the election was historic and will ever remains so for its uniqueness. The votes received by General Mohammadu Buhari (Rtd) was the most nationally spread votes cast since Nigeria's political independence in 1960 and secondly, for the first time in Post Independence Nigeria a Presidential Candidate (General Muhammadu Buhari, Rtd) defeated an incumbent President (Dr Goodluck Ebelle Jonathan) in a presidential poll. This paper therefore, heavily relied on documentary evidences from books, journals, conferences, seminars as well as on printing and electronic media and other related previous relevant literatures provides an explanatory discussion on the reasons behind the defeat of Incumbent President Goodluck Jonathan by General Muhammadu Buhari (Rtd) at the 2015 Presidential race.
\end{abstract}

Keywords: 2015 Presidential Election, Nigeria, Incumbent President, Lost To Buhari

\section{Introduction}

Nigeria after about thirty three (33) years of military rule was liberated from the hands of the dictators on the $29^{\text {th }}$ May, 1999 with the enthronement of and swearing-in of brand new Civilian Administration both at the Federal Capital Territory of Nigeria, Abuja and in the thirty six states capitals of the Federation after a successful conduct of general elections credited to General Abdulsalami Abubakar (now Rtd).

The People's Democratic Party (PDP) ruled for sixteen (16) years sweeping all the four successive presidential elections held from 1999-2011. In 1999, General Olusegun Obasanjo (Rtd) as the Presidential Flag bearer of the People's Democratic Party (PDP) in the 1999 Presidential Election polled 18,738,154 votes representing $62.78 \%$ to defeat his closest opponent Chief Olu Falae of the Alliance for Democracy (AD) who scored 11, 110, 267 representing 37.22\% (Vanguard, April 23, 2011). In 2003 Presidential election, the People's Democratic Party (PDP) maintain its dominion status claiming victory in the presidential election with votes score of 24, 456,140 which is 61.94\% (Vanguard, April 23, 2011). In 2007 while Chief Olusegun Obasanjo is about to complete his second tenure in Office, Alhaji Umaru Musa Yar'Adua became the People's Democratic Party (PDP) Flag bearer. The Presidential election result was then still declared in favour of the People's Democratic Party (PDP) with a total votes cast of 24, 638, 063 (69.60\%) to beat General Muhammadu Buhari (Rtd) of the All Nigeria People's Party (ANPP) who scored 6, 605, 299 which is just 18.66\% (Vanguard, April 23 , 2011). After the count of votes in the 2011 Presidential election results, the People's Democratic Party (PDP) under the Presidential Flag bearer of Acting President, Goodluck Ebelle Jonathan led by a score of $22,495,187$ (58.89\%) as against 12,214,853 which the percentage is $31.98 \%$ (INEC Official Result (2011), Vanguard (April 23, 2011).

It is worth commenting that after the expiration of tenure of President Olusegun Obasanjo in 2007, two different presidential candidates under the People's Democratic Party (PDP) contested the Presidential elections in 2007 and 2011 respectively and won. Though, several reasons may have been responsible for the victory of PDP from 1999-2011, that is not the focus of this study. Worthy to note however, is the fact that General Muhammadu Buhari (Rtd) also was in the Presidential race from 2003 through to 2011. In fact, before the 2011 Presidential race, General Muhammadu Buhari (Retired) adopted another winning strategy through the formation of a new political party, Congress for Progressive Change (CPC) and ascribed to himself the Presidential flag bearer but still could not secure the presidential ticket after the election. Apart from changing political party, General Muhammadu Buhari (Rtd), in 2003, 2007 and 2011 respectively went to court to challenge the victory of the presidential candidates of People's Democratic Party in the three Presidential elections on ground of rigging and manipulation of election results. He however, lost the case in the three instances meaning that his claims were not established by the court of law.

It is in the light of the above development that the researchers of this study scientifically through the chosen methodology investigated the awesome victory of General Muhammadu Buhari (Rtd) in the 2015 
Presidential Election after three successive trials of contesting the Presidential election and three successive lost of cases in the court of law over irregularities which he claimed were responsible for his successive failure to secure the presidential ticket. At the end of the scientific inquiry, the researchers were able to establish the reasons behind the victory of General Muhammadu Buhari (Rtd) in the 2015 Presidential election.

\section{Why is this research justified to be carried out?}

The research is worthy to be carried out because, previous researches carried out on the 2015 Presidential election undertook a comparative analysis of the 2015 and that of 2011 (Araba \& Braimah, 2015), the 2015 elections and the role of electoral management board (Babatunde, 2015), 2015 election and democratic consolidation and change (Adeolu, 2015).

Though, Taiwo \& Bonny (2016) studied the collapse of the People's Democratic Party (PDP) from ruling Party to Opposition party, the researcher in its conclusion section emphasized more on the All Progressive Party as a change agent which adversely affected the PDP and led to its decline from being a ruling party to opposition party. While the researchers for this study tends to agree with Taiwo \& Bonny (2016) that it is the wind of "Change" as preached by the All Progressive Change (APC) that led to the collapse and reposition of the People's Democratic Party (PDP) from "ruling party" to a "watchdog Party", there are several other reasons which their study did not captured that are included in this study. This study reviewed and integrated the work of several scholars together to be able to come out with the reasons for the defeat of the incumbent President Goodluck Jonathan in the 2015 Presidential election which other scholars studied did not do.

On methodology, Taiwo \& Bonny (2016) used direct observation alongside with documentary sources while this study was carried out using explanatory analysis through the use of secondary materials from previous literatures. Once again, the previous studies related to this study do not carry out an in-depth study on only the presidential election but on the elections and the political parties in general. In view of these differences, there is the need to carry out the study using in-depth analysis so as to understand the reasons why the incumbent President, Goodluck Jonathan was defeated in 2015 by the same opponent which won in 2011 Presidential election when he was the Acting President. Finally, the study is important because the general belief is that Goodluck Jonathan would have win Buhari through the influence of the power of incumbency but reverse is the case. In view of this, the study was carried out to academically explain the first incidence in the history of Nigeria's electoral politics where a democratically elected incumbent president was defeated at the poll hence, the need for the study.

\section{Methodology}

Explanatory method of analysis was used to carry out the study while sources of data collection was secondary sources because the secondary sources of gathering data is very useful for a research investigation such as this study as Xaquin (2013) observed, secondary data is very easy to access especially with current development of the internet and secondly, it saves a lot of time. Indeed, big volume of data could be obtain from secondary information just at the point of a click on the search engine in the computer and one will get a whole lots of relevant data without much stress. Once more, using only the secondary sources to undertaking a scientific research study like this is justified because works of many authors, scholars and researchers are integrated and cross-examined at the same time instead of depending on just few selected respondents and or informants as the case may be with primary sources.

In this vein, explaining the issue under study using the explanatory method will not only bring out the relevant and important issues surrounding the defeat of the incumbent President Goodluck Jonathan in the 2015 presidential election but it will go a long way to energize future researchers to use the same method in conducting their future research particularly in understanding the politics of election and its power of change.

\section{Conceptual and Theoretical base of the Study}

It is of paramount importance for all scientific research to be link to a theory as a foundation for analysis. It is also very necessary to provide clear and concise explanations of the inherent concepts while conducting a research therefore; this study is hereby obeying these research scientific research rules and hereby conceptualized and theorized on the study

Election gives the electorates the freedom to choose candidates and also see how accountable leaders are in providing protection for the people against arbitrary rule (Obi and Abutudu, 2015 in Udu, 2015). On the other hand, Momo \& Adejumobi (1999 in Udu, 2015) has described election as a central place in any democracy through the force it provides for representative government and it is also a legitimate instrument in a state under which a state is managed and finally, election ensure political accountability of the elected to the people. In his own line of argument, Braton in Udu (2015) says that election is a fundamentally important instrument both for installing democratic government in a state and a necessity for consolidating democracy. 
Diamond, 1990, Jinadu, 2003 as presented by Udu (2015) stressed that election could only be said to be election in its real meaning when it is conducted under the concept of free and fair situation and it is able to present a credible leader (s) to represent the people. Anything outside these requirements cannot be said to be election and cannot seems to be so and would not be accepted to be so by the people. Finally on concepts of scholars perception relating to election, Akubor (2015) admitted that election has created a way through which people perform their rights to determine the people they intends to entrust their leadership mantle to. The shortcomings associated with this definition could be corrected if it is defined that election has created a way through which people perform their political civic rights to determine the people they intends to entrust leadership mantle to through the poll.

We could deduce from the conception of the scholars that, election is a credible instrument which is used by the electorates or voters to select their leaders and representatives into the legislative and executive arms of government. The leaders so to be elected must be accountable to the people fair representation and they must be selected at the poll through free, fair and transparent electoral processes that will be accepted by all as true picture of their mandate.

In other words, election is a powerful instrument of the electorates which through it the people transfer their mandate and authority to the leaders at the poll to represent them in the legislative house and executive chambers and to freely discuss and transform all issues affecting them into a policy for the betterment of their welfare. Finally, let us add that election is the voice of the people that is spoken at the poll through the ballots as to who should be their leaders and or representatives in policy making and execution process for the betterment of all and sundry in the society.

\section{Theoretical Framework}

Though, there are several theories on incumbency such as incumbency and the theory of political Ambition: A rational-choice Model (Levine \& Hyder, 1977). The Incumbency Advantages in U.S. Election: An Analysis of States and Federal Offices, 1942-2000 (Ansolabehere \& Snyder, 2002) and others. Their main argument is hinged on argument that incumbents are highly advantaged over non-incumbents in winning election.

However, the theory which this work leans on is the theory of "Corruption and the Incumbency disadvantage: Theory and Evidence. The theory is credited to Klasnja (2015). The main thrust of the argument of this theory is built on the challenges and significant disadvantages that incumbents will face when incumbents tends to seek re-election after their first tenure which is contrary to what is obtainable in the United States of America. Secondly, the theory holds that incumbent electoral contestants become more disadvantaged when corruption is traced to them especially when the gain accruing to the incumbent through corruption is increasing as the he spends more time in office.

The theory was first used to test innovative measures of local corruption in Romania. The main criteria that were used to test the theory includes: national rules tying to mayoral salaries to population thresholds that cause jumps in the opportunity cost of corruption and thus its incidences and secondly, close elections that assign incumbency as if randomly". The findings according to Klasnja (2015) shows that, most of the incumbency disadvantages that were found in local elections are tied to corruption and the highest percentage of the corruption is linked to Romanian mayors.

As a supporting theory to the main theory of this work, summarily, Onnstein (1990) in his theory of "Incumbency Theory Doesn't Explain All" has also theorize to argue that despite the existing proof by several theories that incumbency has greater advantages in the House in U.S. of 98 percent to 98.4 percent when it comes to winning election except only in exceptional cases is partial and it is applicable to where there is a control of one party democracy. Evidences as Onnstein (1990) submits, has proved beyond reasonable doubt that reelection rates for incumbents has not only been very high for over a century (in the U.S) but as high as an average of more than 90 percent stands to attest for and support this argument. More importantly, "Since 1954 Republicans have won 77 open Democratic seats in the House of Representatives; Democrats have won 101 open Republican seats" (Onnstein (1990). Stressed further, Onnstein (1990) has challenged the incumbent theories that if incumbency advantage as they claim is true the above open fact of winning vacant seats of incumbent by opposition candidates would have been proved wrong.

Both the above theories and the 2015 Presidential election where the incumbent President Goodluck Jonathan was defeated by an opposition (Gen. Muhammadu Buhari, Rtd) fits into a round, square, triangle and oval holes in this article. This is justifiable on ground that the theories agreed that an incumbent could be defeated in extreme circumstances as it is applied to U.S Congress House. It is the same extreme case that occurred in Nigeria in 2015 for General Muhammadu Buhari (Rtd) to defeat Jonathan Goodluck the then President of Nigeria being the first time an opposition presidential candidate defeated an incumbent president after fifty seven (57) years of Nigeria's political Independence from the British Colonial Masters. 
In line with the above, the researchers wish to humbly submits that beyond reasonable doubt, the above theories provides a solid academic base on which this research work could be carried out hence, the researchers progressed to carry out the work accordingly. For the sake of academic clarification however, let's go a step forward to provide a prelude for reasons why the researchers chose the above theories for the study

\section{Reasons for Chosing the theories in the Theoretical Framework}

We tend to portray the influential aspect of incumbency in the global democratic countries so as to see why we chose the theories used in our theoretical framework. Incumbents are the political office holders who usually during elections has numerous advantages over other contestants, challengers or oppositions for many reasons (Gordon \& Landa, 2009 cited in Nwanebgo \& Alumona, 2011). It is further stressed by Olusola-Obasa (2011) in Okoye, Egboh and Chukwuemeka (2012) refers to the open-ended opportunities that these groups of people have access to their state resources more than other challengers in election who are not within the state apparatus. Incumbency factor as addressed by such have access to state resources and machinery by ruling political leaders holding political positions. Nwanebgo \& Alumona (2011) citing Ansolabehere et al (2005) maintains that one of the most well documented noticeable feature in western democratic elections particularly in the United States of America is incumbency factor while Okoye, Egboh and Chukwuemeka (2012) adds that the advantages of the incumbency is one among the most active debatable topics in America politics particularly since the quarter of this century back..

It has been pointed out that funding modern campaign in America politics is said to be very expensive (Lumen, American Government). In the document, it was said that from year to year, the campaign funding continue to swell up. While in 1986 Congress seat campaign costs US\$ 776, 687 and US\$6,625, 932 respectively to run election for House \& Senate. In 2014, it rose to US\$ 1,466,533 and US\$ 9,655,660. In line with the above: Campaign financing regulations and loopholes is more easily navigated by incumbents in congress than by newcomers. The amount of money they (incumbents) raise against their challengers demonstrates their advantage. In 2014 for example, the average senate incumbent raised US\$12, 144,933 whereas the average challenger raised only US $\$ 1,223,566$. This is one of the many reasons incumbents win a large majority of Congressional races each electoral cycle. Incumbent attract more money because people want to give to a winner. In the House, the percentage of incumbents winning reelection has hovered between 85 and 100 percent for last half century.

In Africa, it has been debated that incumbency is a big factor in electoral politics. In fact, Nwanebgo \& Alumona, 2011; Mozaffer \& Schedler, 2002 have categorized incumbency factors in democratic election to include making and changing of rules, execution and applying of regulations and finally, the adjudication of legal statutes. Generally, the power of the incumbency in these three areas according to Mozaffer and Schedler (2002) ranges from enacting and re-enacting of rules, appointing compromising individuals into the offices of the electoral management boards as well as judicial officials of electoral tribunals, using state security forces to intimidate opponents in opposition party or parties before, during and after election. Others includes denial of campaign venues as well as denial of media owned by the state and many other ways of influencing the entire electoral processes. This is very common in African countries particularly in Nigeria.

In the Nigeria elections held from 1999-2011, Nwanebgo \& Alumona (2011) acknowledged that the 2003 and 2007 general elections conducted under the then President Olusegun Obasanjo is characterized by abusive use of the incumbency to frustrate the opposition parties in order to avoid the alternation of political power from the ruling People's Democratic Party (PDP) to other parties which resulted in electoral violence that featured in the Obasanjo administration and threatened democratic consolidation. Okoye, Egboh and Chukwuemeka (2012) also asserts that a fledgling democracy in Nigeria is characterized by bottlenecks which is worsened by the negative influence of incumbency in politics because of their open access to state resources and machinery describing the process of power transfer in Nigeria to be different from the procedures in the western world such as United states and other new states

We drew the examples from America, Africa and Nigeria to enable us justify and prove beyond reasonable doubt that incumbency factor plays an influencing role in every election irrespective of whether the country is democratically consolidated as the case with the United States or not. This inference will now help us to justify that incumbent leaders maximally utilizes incumbency advantages to oppress the opposition parties, rig and manipulate election results so as to remain in power. This development has been the bane to free, fair and credible elections in Africa and Nigeria over the years particularly since the multiparty politics from the early 1990 s to date.

It is in the light of the above that the researchers are undertaking this study in order to verify, determine and establish the reasons behind the failure of incumbent President Goodluck Jonathan in 2015 presidential election despite the fact that he has all the wherewithal of incumbency executive powers influence the 2015 Presidential election result in his favour. It is on the above premise that we feel that the theory of Corruption and the Incumbency disadvantage: Theory and Evidence" credited to Klasnja (2015) and Onnstein (1990) 
"Incumbency Theory Doesn't Explain All" to show that there are exceptional situations that incumbency does not count in electoral politics as the case with the 2015 Presidential election in Nigeria that is under study in this work.

\section{Brief on the 2015 Presidential Election in Nigeria}

Nigeria discarded the Parliamentary system of government in favour of the Presidential system of government modeled after the system of government in the United states of America. This followed the birth of the first indigenous constitution, the 1979 Constitution of the Federal Republic of Nigeria under which a general election was conducted in 1979 and the First Executive President of the Federal Republic of Nigeria, Alhaji Shehu Usman Aliyu Shagari was elected and duly sworn-in on the $1^{\text {st }}$ of October, 1979. Since then, the office of the head of state and head of government is headed by a single individual called the "President".

The 2015 Presidential election was the fifth Presidential elections held in Nigeria since $29^{\text {th }}$ May, 1999 when Nigeria's Fourth Republic was inaugurated. The election was held on the $28^{\text {th }}$ March, 2015 in the seven municipal councils of the Federal Capital Territory, Abuja and the 774 local governments across the 36 states in the Federation of Nigeria. The election marked the fourth successive presidential race contested by General Muhammadu Buhari (Rtd) from 2003 through to 2015 and it was the second presidential race contested by Goodluck Jonathan after the 2011 Presidential election which he won.

After the election was concluded and results was released officially by the Independent National Electoral Commission (INEC), General Muhammadu Buhari (Rtd) of the All Progressive Congress (APC) defeated the incumbent President Goodluck Jonathan and other twelve (12) Presidential aspirants after scoring fifteen Million, four hundred and twenty four thousand, nine hundred and twenty one $(15,424,921)$ votes as against twelve million, eight hundred and fifty three thousand, one hundred and sixty two $(12,853,162)$ scored by Incumbent President Goodluck Jonathan (INEC, 2011). The total average score for All Progressive Party (PDP) is 53.96\% of the votes as against People's Democratic Party (PDP's) $44.96 \%$ which represents a margin of 2,571,759 (Adeolu, 2015). Apart from scoring the highest majority votes, Buhari was able to score $1 / 4$ of the total votes casts in 2/3 of the states in Nigeria as required by the 1999 Constitution of the Federal Republic of Nigeria as (amended). That is, he scored the 25/100 (25\%) votes in 24/36 states required by the law. This condition is similar to the Electoral College votes in the United States of America.

\section{Defeat of Incumbent President Goodluck Jonathan in the 2015 Presidential Race in Nigeria}

Several scholarly articles related to the 2015 Presidential election that deals particularly with the reasons for the defeat of incumbent President Goodluck Jonathan by Muhammadu Buhari (Rtd) were reviewed by the Researchers of this study. The key documents reviewed includes Araba \& Braimah (2015), Babatunde (2015), Adeolu (2015). Udu (2015), Akubor (2015), Taiwo \& Ayodele (2016) and others.

One of the issue that endanger President Goodluck Administration from 2011 to 2015 which he failed to address before he went for the presidential race in 2015 was the stigma of corruption. Araba \& Braimah (2015) proved this by saying that the current Emir of Kano, Sanusi Lamido, while serving as the Central Bank of Nigeria (CBN) Governor under President Goodluck Jonathan raised alarm of a missing US\$ 40 billion of revenue accruing to the Federation Account (FA) from the Nigeria national Petroleum Corporation (NNPC). Apart from this, in 2013 still under the President Goodluck Jonathan rule, under the "Corruption by Country" rating of the Transparency International (A Global Watchdog of Corruption and its related activities), ranked Nigeria as the $144^{\text {th }}$ out of 177 . The stories of woes of corruption of the Goodluck Jonathan Administration from his cabinet members chiefly, the petroleum minister, Allison Madueke were well exposed and documented after he handed over to President Muhammadu Buhari on the $29^{\text {th }}$ May, 2015. Several of Goodluck's Cabinet members were accused of stolen money and selfishly enriched themselves from public monies. In 2015 election he lost the presidential election which many believed was attributed to the high level of corruption he allowed under his administration from 2011 to 2015.

Most of the scholars whose works were reviewed strongly believed that a major lost of victory by President Goodluck Jonathan in the 2015 Presidential election could be explained from the angle of the kidnapping of the over 200 Chibok girls from a secondary school in Chibok, Borno State, Nigeria by suspected Boko Haram insurgents (Araba \& Braimah (2015). President Goodluck Jonathan did virtually nothing about the missing girls and like other past does, he did not even visit Borno State during the time of the incident of the kidnapping to sympathize with the parents of those girls. Internationally and nationally, this development made the world powers and the entire world to lose confidence on President Goodluck Jonathan as a credible President capable of defending his citizens. There was a global and national peaceful demonstration over the missing girls when nothing was done by the President over the issue for nearly a year. This global demonstration was organized mostly by women. This spelled doom for the People's Democratic Party (PDP) and the Candidacy of President Goodluck Jonathan in the 2015 Presidential election. 
One other thing that cracked the People's Democratic Party shell and allowed its resources for winning election to leaked out is the factionalization of the party. By 2013 November, following a tussle over Chairmanship of Governor's Forum leadership in the People's Democratic Party (PDP), five PDP serving governors including Rabiu Kwankwaso, the then Governor of Kano State, Murtala Nyako (Adamawa State Governor), Rotimi Amaechi, River State Governor, Aliyu Wamako, Sokoto State Governor and finally, Abdulfatah of Kwara State. All effort to reconcile and unite the Party (PDP) failed. Coupled with the above, mass decamping to the All Progressive Congress (APC) by PDP members were very rampant from 2013 to 2015 particularly the "49 PDP Federal Legislators" (Adeolu, 2015) which swell up the APC Legislators in the Lower House (House of Representatives) to 186 out of 360 members. The defection of PDP members to All Progressive Congress (APC) was on a continuous basis up to the time of the presidential election in 2015 coupled with the resignation of Bamanga Tukur, the PDP National Chairman in 2014 also affected the PDP in the 2015 presidential election because Nigerian electorates lost confidence on the party following the happenings in the party.

In a related development, former President of Nigeria (1999-2007), Olusegun Obasanjo towards the period of the election also defected from the People's Democratic Party (PDP) to All Progressive Congress (APC). His case of defection needed to be discussed further because of its importance. In Adeolu (2015, P 178), Obasanjo was quoted saying "I have reason to believe that most or should I say all of you are wondering why I have chosen to defect to the APC and I must say that if I had been told that I would have to switch party some 5 years ago, I myself would have argued it. I believe in transparency and integrity but unfortunately, PDP is an opposite of such attributes". (See OBJ Defects To APC And Calls Jonathan Administration, "Useless Government"). Apart from the fact that former President Obasanjo made this speech in form of world press conference, he also brought out his PDP membership card and publicly torn it into pieces. His action has high negative implication in the presidential election Goodluck Jonathan lost in 2015. In the first instance, all Nigerians knew how politically powerful the Former President Olusegun Obasanjo is in Nigeria and he worked for Goodluck Jonathan to triumph in the 2011 Presidential race because he was solidly behind Goodluck and for him to acted the way he did spelled a disaster for Goodluck Jonathan and the People's Democratic Party (PDP) in 2015 Presidential election

Again, Obasanjo was a major pillar which supported PDP and sustained it for the sixteen years rule from 1999-2015 therefore, just like a building, the PDP collapsed when the pillar holding it failed. Once more, President Olusegun Obasanjo, is a renowned international and national figure and any of his action has a close connection to international and local affairs therefore, the demise of PDP as a party was as a result of Obsasanjo's decamp and denounce of the party.

In line with Adeolu's (2015) argument in favour of why Buhari defeated incumbent President Goodluck Jonathan, the role of the Permanent Voter's Card (PVC) cannot be underestimated. The Card have biometric inscriptions including chips and it contains all information of all the holder of the card and it was purchased by the Independent National Electoral Commission (INEC) after the fund was approved and made available to INEC by the Federal Government headed by President Goodluck Jonathan.. The cards on Election Day were used by electoral officials through an electronic Hardware called "Card Reader". The Cards which were test-ran before the Election Day reduced the incidences of electoral fraud to a reasonable extent. Rationally, one could argue that the introduction of PVC and the Card Reader helped Buhari to have won the election because the rate of rigging and manipulation of final results declared was highly reduced.

In the Northern region the strongest home base of presidential aspirant of the All Progressive Congress (APC), Buhari have a landslide victory in the election with Kano State alone with over two Million votes in favour of Buhari. Though, the Northerners are the most politically conscious people in Nigeria, the rate of voter turnout in the North in the 2015 presidential election were awesome. The entire people of the Northern region massively voted for Buhari at the poll. Apart from this, the election was postponed for six weeks to enable the Boko Haram insurgents be pushed away. This was achieved to some extent and the registered voters in the North East of Nigeria were able to vote for Buhari as the 2015 Presidential election results from that axis proved.

One very important reason gave by Udu (2015) in his contribution to the reasons for the triumph of Buhari over the incumbent President Goodluck Jonathan in the 2015 presidential election is what he described as "formidable Presidential Candidate of the All Progressive Party, APC". President Goodluck Jonathan frankly speaking was not able to withstand General Muhammadu Buhari (Rtd) in the 2015 Presidential race because he lacks any strong backing as the case with the 2011 Presidential election that he won on the platter of gold and silver. Buhari is such formidable candidate even right from the 2003 when he started contesting for the presidential position. He could not be able to defeat the then incumbents possibly because of unforeseen reasons which is not within his control. In the 2015, virtually the masses stood for Buhari's candidature and voted for him on the Election Day. The voters defiled rain and sunshine and any weather, waited on the queue and cast their vote for him. Buhari's personality as a man of proven integrity from his short-lived administration as a 
Military Head of State between $31^{\text {st }}$ December, 1983 to $27^{\text {th }}$ August, 1985 attests to this fact. In 2015 (after 30 years as a military Head of State), his integrity lived after him. Even the young generations who voted for him during the 2015 Presidential election who were not born then heard the story of Buhari from their parents and guardians and everyone was determined to see him reclaim his Presidential seat which he did..

The All Progressive Party (APC) as a Party apart from its Presidential Candidate being a formidablepersonality also emerged after its formation with a slogan. Emblem/motto "CHANGE" that fitted and suited the 2015 election situation when every average Nigeria needed a party that will come and change and replace the People's Democratic Party. APC got the formula and the formula "CHANGE" saw the party through to have swept the elective seats from the Presidency through to the National Assembly members to the state governors, states house of assembly members as well as the local government councilors. Indeed, it was a wind of change that blown away the People's Democratic Party (PDP) from the political seats in Nigeria. In fact, just like Heroclitus's aphorism in Taiwo and Ayodele (2016), "Change is the only constant thing in life, thus, everything is in a state of constant flux, and the idea of fixity is nothing but an illusion of the senses". As a result of the above, a vote for Buhari and the All Progressive Party (APC) in 2015 general election was regarded as vote for a man and a party who will come and liberate Nigerians from their afflictions inflicted on them by the People's Democratic Party for sixteen years and as result of that Buhari and almost anyone that linked itself to the Party (APC) in 2015 election won the elective seat.

Virtually, in all the states of the Federation before the Presidential election of 2015, the People's Democratic Party (PDP) governments both at the centre and the states were no longer a responsive government to the people any longer. Salaries arrears of Nigerian workers at the states were running to nine months and not that these state governors were being owed the monthly allocation meant for the salary from the Federation Account. Still at the end of every month they go to Abuja to collect their money and the Government under Jonathan did nothing about it. Children of these civil servants stopped going to school due to lack of school fees and even feeding was became a big problem for larger percentage of civil servants in the states across the Federation.

The Handwriting on the wall of the Nigeria 2015 presidential election clearly read that President Goodluck Jonathan will lose the election no matter what he does. In some states of the country such Bauchi, Katsina during the Presidential campaign, his campaign entourage was attacked by suspected All Progressive Congress supporters believed to be loyal to Muhammadu Buhari, the strongest challenger in the 2015 presidential election (Vanguard, 21 January 2015). Similar attack was also launched on President Goodluck Jonathan in Bauchi during the campaign tour. As Najib (2015) put it, "President Goodluck Jonathan's reelection campaign in Bauchi on Thursday turned violent when some thugs who converged at the Ibrahim Babangida Square, venue of the event, hurled shoes, plastic water bottles and other objects at the canopy where the President and members of his campaign team were delivering their speeches". It took the intervention of the security to bring the situation under control and in the process one of the Police vehicle was set on fire. Down South-South geo-political zone, the region where Goodluck Jonathan hailed from, Rivers State in particular (the home State of President Goodluck's wife), the then Governor of the State, Rotimi Amaechi refused to approve Adokiye Amiesimaka Stadium in Port Harcourt for Goodluck to use as campaign venue until President Goodluck used his office as military fiat to seal up the Stadium with Soldiers (Premium Times, January, 25, 2015). It was based on these developments that President Goodluck Jonathan scored very low votes particularly in the affected Northern states during the 2015 Presidential election.

Annexation of parts of the North Eastern Nigeria by Boko Haram insurgency constitutes another factor why Goodluck Jonathan woefully failed the Presidential election in 2015. Almost all the literature consulted includes Araba \& Braimah, 2015; Babatunde, 2015; Adeolu, 2015; Udu, 2015; Akubor, 2015; Taiwo \& Ayodele, 2016 attest to this claim. The Boko Haram insurgence was advanced fiercely and keeps reclaiming villages and town in Adamawa, Yobe and Borno States respectively towards the 2015 general elections and the Government under President Goodluck as far as Nigerians particularly those from the North Eastern part of Nigeria is concerned did nothing therefore, they cannot risk their vote on a President who cannot protect them, their land and properties for another four years consequently, President Goodluck Jonathan lost the election despite his tactics of postponement of the Presidential election.

Disobedience to the People's Democratic Party (PDP)'s “zoning” conventional agreement was responsible for failure of President Jonathan in Presidential election in 2015 in Nigeria. Prior to the death of President Shehu Musa Yar'Adua in May 2010, there was an arrangement within the People's Democratic Party (PDP) to rotate the Presidential seat between the Southern and the Northern region for eight years of two terms of four years each. Chief Olusegun Obasanjo, a Southerner benefitted from this arrangement first from 19992011. He respected the agreement and went extra miles by campaigning and canvassing for Yar'Adua even up to the point of "do or die affair"(as Obasanjo put it) in 2007 Presidential election and Yar'Adua won the Presidential election. When Yar'Adua died in 2010, Goodluck Jonathan, a Southerner deputizing for him became an automatic Acting President. The North expected him to organize the 2011 election and handover to 
another Norterner who will complete the eight years tenure of the North but he instead gunned for the presidency and won the seat in the Presidential election in 2011. Jonathan's decision to stand in 2011 alienated many northerners in the PDP who felt that it should be the north's turn again. The breakdown of the PDP's informal zoning arrangement in 2011 did not in the end greatly damage Jonathan's prospects. He won a convincing victory. But there are those who argue that by overturning the zoning arrangement, he seriously destabilised the country's ruling elite...(House of Common Library, 2015). The Notherners as a result of the above may have thought that Goodluck trickly want to still steal their chance of Presidency and that may be responsible for the landslide victory of Buhari in the 2015 presidential election.

\section{Concluding Remarks and Recommendations}

The 2015 presidential election under study with particular reference to the landslide victory of Buhari over the incumbent President Goodluck Jonathan at the poll signifies a lot going by the reviews of documents available to the Researchers and used accordingly. The documents consulted signified that despite the fact that the incumbent President has all the wherewithal of the state apparatus namely the financial, material, the state security, the electoral management board, etc under his control, he lost the 2015 presidential election glaringly to the strongest opposition challenger, Muhammadu Buhari. with a very wide margin.

The outcome of our investigation from the available literatures we reviewed proved that exceptional cases or circumstances just occurred in the 2015 Presidential election where an incumbent lost to an opposition. In line with this scenario therefore, the two anchor theories of this work holds because the theories all agreed that exceptional cases exist where incumbents party/leader sometimes lost to opposition leader/party in an election despite the incumbency advantages that may exist.

Summarily, the documents reveals that several factors aided the incumbent to lose the election to the opposition candidate in the 2015 Nigeria presidential election. Chiefly among the factors are, the poor performance of the People's Democratic Party (PDP) in the last sixteen years, the All Progressive Congress (APC) launched a slogan of "CHANGE" and used same as the acronym of manifesto which was very timely in Nigeria and among Nigerians who desperately needed a change at that time (2015) so as to free themselves from the bondage of the People's Democratic Party such as the non-payment workers' salary at the state level, insecurity of Boko Haram that was then very serious and threatening the territorial integrity of the country which turned hundreds of thousands of children to orphans after killing and abducted their parents, take away able bodied men and young ladies especially the over 200 Chibok Secondary school girls, displaced hundreds of thousands of people from their home origin, destroyed properties that cannot be estimated coupled with the high rate of corruption evidently proved beyond reasonable doubt by Transparency International. In view of the above, the Nigerian electorates massively turned out on the days of the general election to vote for most candidates of the All Progressive Congress (APC) including the presidential candidate, General Muhammadu Buhari who gallantly defeated incumbent Goodluck Jonathan.

While the researchers are not claiming to have exhausted the factors responsible for the victory of an opposition leader of the All Progressive Congress (APC) and the vanquish of incumbent President of the then ruling Democratic Party (PDP), the analysis so far are said to be some the reasons adduced from th documents consulted and the idea of the researcher which one of them is a Nigerian by birth and stays and has been working in Nigeria for almost two decades and also a participant in the 2015 Presidential election, it is believed that the factors raised are to the best of the researchers correct.

However, while these enumerated factors are obtained from the available literatures that the researchers have access to, Adeolu (2015) when attempting to conceptualize democratic consolidation said it is all about whether it is possible under a consolidated democracy (let's also add by saying emerging consolidated democracy) for the former authoritarian regime to sustain their newly discovered democracy? The answer is no. Democratic Consolidation demolishes authoritarianism and an entrenched ideal democratic principle as Dahl (1989) puts. At a stage after some years of practice of democracy like the case of Nigeria from 1999-2015, democratic consolidation on its own will naturally germinate because democracy will also naturally correct some of the inherent characteristics of authoritarianism on its own without anyone deliberately instituting or correcting features of authoritarian rule and this will naturally serve as a fertile nutrient for democratic consolidation to sprout.

It is not a hidden fact in Nigeria that the People's Democratic Party particularly from 1999-2007 was well known for electoral irregularities for instance, it is said that "Nigeria has had a checkered electoral history with successive elections being marred by serious irregularities and controversy-particularly in the conduct of its electoral commission. This has led in some cases to the collapsed of democratic experiments as occurred in 1966 and 1983 ... According to several local and international observers... the 2007 turned out to be the worst election in Nigeria's political history (European Union: 2007, Human Rights Watch: 2007, Transition Monitoring Group: 2007 (Araba \& Braimah, 2015, p. 49). Therefore, it is the invisible hands of democratic consolidation that worked against the People's Democratic Party (PDP) and incumbent President Goodluck 
Jonathan in the 2015 presidential election. Take for instance, President Goodluck on his own approved the funds used in buying Card Readers Hardware and in running a credible election which worked against rigging, manipulation and falsification of election results. Indeed, the law of democratic consolidation is an iron fist in applying itself and no incumbent can stop it when it is ripe for to sprout out in a democracy no matter how strong the incumbent seems to be. The same conclusion was drawn by Odoh \& Salisu (2017) when they were summarizing the reasons why Donald Trump defeated Hillary Clinton in the November 8, 2016 United States Presidential election. They asserts that "where democratic consolidation has grown to a giant and flamboyant height like the United States of America, there will always be invisible and unseen hands that will forcefully push aside incumbent government from the government house".

While it will be wrong to equate Nigeria emerging Democracy to the highly consolidated democratic State like the United States of America, it is pertinent to note that democratic consolidation varies in stages and stature and by every standard we are academically comfortable to say that democratic consolidation is in its foundation stage in Nigeria politics even though, it is yet to fulfill Huntington's (in Durotoye (2015) law which states that a country's democracy is only consolidated when incumbent party or leader is dethrone twice through a democratic election. It is suffice to say that democratic consolidation just started in Nigeria because Nigeria is in the democratic "process of achieving broad and deep legitimation such that all significant political actors including Nigerian presidents as the case will soon believe just as the case with Goodluck Jonathan in 2015 that popular rule is better for our society than any other alternative they can imagine based on Diamond (1999) position.

In view of the above, we wish to recommend that all successive government in Nigeria in the future should know that the era of electoral irregularities is over and the people will demand for accountability, prudency in the management of the nation's resources which must be use for Nigeria infrastructure development that will not only be capable of enhancing lives of the people but improve the per-capita income, raise standard of living and eliminate abject poverty.

\section{Reference}

[1]. Adeolu D. (2015). Nigeria's 2015 Presidential Election: Between Democratic Consolidation And Change. European Scientific Journal. July edition. Vol.11, No.19. Available online at http://eujournal.org/index.php/esj/article/viewFile/5936/5721

[2]. Akubor, E.O. (2015). Campaigns and Electioneering: Reflecting on the 2015 General Elections in Nigeria. Paper presented at the Two-Day National Conference on "The 2015 General Elections in Nigeria: The Real Issues"; Organized by the Electoral Institute, Abuja. Venue : Electoral Institute Complex, INEC Annex, Opposite Diplomatic Zone, CentralBusiness District, Abuja. 26th - 29th July. Available online at http://www.inecnigeria.org/wp-content/uploads/2015/07/Conference-Paper-by-_ EmmanuelOsewe-Akubor.pdf

[3]. Ansolabehere, S. A. \& Snyde, J,M Jr. (2001). The Incumbency Advantage in U.S. Elections: An Analysis of State and Federal Offices, 1942-2000. http://economics.mit.edu/files/1205

[4]. Araba, A. A \& Braimah, J.O. (2015). Comparative Study of 2011 and 2015 Presidential Elections in Nigeria. Available online at https://globaljournals.org/GJHSS_Volume15/4- Comparative-Study-of-2011.pdf

[5]. Babatunde, O. (2015). 2015 General Elections And The Role Of Inec. http://www.inecnigeria.org/wpcontent/uploads/2015/07/Conference-Paper-by-Tunde- Oyekanmi.pdf

[6]. Diamond Larry, "Developing Democracy: Towards consolidation”, Baltimore, (1999) in Adeolu D. (2015). Nigeria's 2015 Presidential Election: Between Democratic Consolidation And Change. European Scientific Journal. July edition. Vol.11, No.19. Available online at http://eujournal.org/index.php/esj/article/viewFile/5936/5721

[7]. Durotoye, A. (2015). Nigeria's 2015 Presidential Election: between Democratic Consolidation and Change. European Scientific Journal. Vol.11, No 19. July 2015. Pp 169-184. Available online at http://eujournal. org/index. php/esj/article/ viewFile /5936/5721

[8]. House of Commons Library. (2015). Nigeria 2015: Analysis of election issues and future prospects. RESEARCH PAPER 15/02 19 January. Available online at file://C:/Users/user/Downloads/RP15-2\%20(1).pdf

[9]. Independent National Electoral Commission (INEC). (2011). Report on the 2011 General Elections retrieved from http://www.inecnigeria.org/wp-content/uploads/2013/07/REPORT-ON-THE-2011-GENERAL- ELECTIONS.pdf

[10]. Independent National Electoral Commission (INEC). Official General Election Results (2011). Available online at http://www.inecnigeria.org/?page_id=31

[11]. Klašnja, M. (2015)Corruption and the Incumbency Disadvantage: Theory and Evidence. The Journal of Politics. Vol.77, No. 4. October. $\quad$ http://www.journals.uchicago.edu/doi/pdfplus/10.1086/682913

[12]. Levine, M.D \& Hyde, M.S (1977). Incumbency and the Theory of Political Ambition: A rational Choice Model . The Journal of Politics. Vol.39. No 4. Pp 959-983. Available online at https://www.jstor.org/stable/2129937?seq=1\#page_scan_tab_contents

[13]. Lumen: American Government. Available online at

https://courses.lumenlearning.com/amgovernment/chapter/congressional-elections/

[14]. Naji, S. (2015). Youth Attack Jonathan in Bauchi. Premium Times. 22 January. Available online at http://www.premiumtimesng.com/news/top-news/175443-youth-attack-jonathan-in-bauchi.html

[15]. Nwanegbo, J. \& Alumona I.M. (2011). Incumbency factor and Democratic Consolidation in Nigeria's fourth Republic. The Social Science 6(2). 125-130

[16]. Odoh, P.A. \& Salisu, A. (2017). 2016 United States of America'spresidential Election: Reasons Why Donald Trump Won. IOSR Journal of Research \& Method in Education (IOSR- JRME) Volume 7, Issue 2 Ver. I (Mar. - Apr. 2017), PP 80-90. Available online at www.iosrjournals.org

[17]. Okoye, J.C, Egboh, E.A \& Chukwuemeka, E.E.O. (2012). Changing Perspectives of Nigeria political Development: From Militarism to Incumbency and godfatherism. Journal of Political Studies. Vol 19, Issue, p 1-17 
[18]. Ornstein, N. (1990). Incumbency Theory Doesn't Explain All. Chicago Tribune. October 27. Available online at http://articles.chicagotribune.com/1990-10- 07/news/9003230311_1_incumbents-republicans-seats-and

[19]. Premium Times. (2015). Jonathan, Amaechi in fresh showdown as soldiers take over Port Harcourt stadium. $25 \quad$ January. Available online at http://www.premiumtimesng.com/news/top- news/175552-jonathan-amaechi-fresh-showdown-soldiers-

take-port-harcourt-stadium.html

[20]. Taiwo, O. A. \& Bonnie, A. (2016). From The Ruling To The Oppostion Party: Nigeria's People's Democratic Party And The Dynamics Of Change. American Journal Of Innovative Research And Applied Sciences. Issn 2429-5396 I www.AmericanJiras.Com. I47-159. Available online at https://american- jiras.com/TAIWO\%20ManuscriptRef.3-ajiras200216.pdf

[21]. UDU, L.E. (2015). INEC and the 2015 General Elections in Nigeria: Matters Arising. Research on Humanities and Social Sciences. Vol.5, No.12. Available online at http://www.iiste.org/Journals/index.php/RHSS/article/viewFile/23446/24161

[22]. Vanguard. (2011). Presidential Elections 1999-2011 in Figures. April 23. Available online at http://www.vanguardngr.com/2011/04/presidential-elections-1999-2011-in-figures/

[23]. Vanguard. (2015). Nigeria: Suspected APC's Supporters Attack Jonathan's Convoy, Destroy Billboard. Vanguard (Lagos), 21 January. Available online at http://allafrica.com/stories/201501211463.html

[24]. Xaquin, S. P. L.(2013). Advantages And Disadvantages Of Secondary Data Collection Nowadays. Available online at https://xaperezsindin.com/2013/12/11/advantages-and-disadvantages-of-secondary-data- collection/ 